NBER WORKING PAPER SERIES

\title{
OWNERSHIP CHARACTERISTICS, REAL EXCHANGE RATE MOVEMENTS AND LABOR MARKET ADJUSTMENT IN CHINA
}

\author{
Risheng Mao \\ John Whalley \\ Working Paper 17565 \\ http://www.nber.org/papers/w17565
NATIONAL BUREAU OF ECONOMIC RESEARCH
1050 Massachusetts Avenue
Cambridge, MA 02138
November 2011

We are grateful to the financial support from Ontario Research Fund (ORF) and comments from seminar participants in the department of economics, University of Western Ontario, Canada. The views expressed herein are those of the authors and do not necessarily reflect the views of the National Bureau of Economic Research.

NBER working papers are circulated for discussion and comment purposes. They have not been peerreviewed or been subject to the review by the NBER Board of Directors that accompanies official NBER publications.

(C) 2011 by Risheng Mao and John Whalley. All rights reserved. Short sections of text, not to exceed two paragraphs, may be quoted without explicit permission provided that full credit, including $\odot$ notice, is given to the source. 
Ownership Characteristics, Real Exchange Rate Movements and Labor Market Adjustment

in China

Risheng Mao and John Whalley

NBER Working Paper No. 17565

November 2011

JEL No. F16,F31,J21,J31

\begin{abstract}
This paper uses a firm level multi-industry data set covering 456 Chinese manufacturing sectors to assess the implications of Renminbi (RMB) real exchange rate appreciation for adjustments in employment and wage rates. We stress differences in both industry and firm characteristics within sectors. Our empirical results show that modest (and also larger) RMB real exchange rate appreciation would likely have pronounced effects on both net employment and wage rates. A 10\% RMB appreciation would likely cause a net employment decline in Chinese manufacturing industries of between $4.1 \%$ and $5.3 \%$, and a wage rate drop of $4 \%$ after controlling for other factors. Real exchange rate change effects by industry on net employment and wage rates vary significantly with the ownership characteristics of firms within industries. Employment and wage rates for private enterprises are less responsive to RMB real exchange rate fluctuations than is true for state owned enterprises (SOEs) and foreign invested enterprises (FIEs). This finding is opposite to the widely held belief that the labor market behavior of Chinese SOEs shows stronger labor market rigidities than for private firms. Impacts of exchange rate movements emerge as systematically related to export openness, overall import penetration and profit margins of individual manufacturing industries.
\end{abstract}

\author{
Risheng Mao \\ Institute of World Economics \& Politics \\ Chinese Academy of Social Sciences \\ No.5 JianGuoMenNeiDajie \\ Beijing, China 100732 \\ gilbertmao@gmail.com \\ John Whalley \\ Department of Economics \\ Social Science Centre \\ University of Western Ontario \\ London, ON N6A 5C2 \\ CANADA \\ and NBER \\ jwhalley@uwo.ca
}




\section{Introduction}

Recent empirical studies on the labor market implications of exchange rate change typically find a significant relationship between exchange rate fluctuations and labor market adjustments in a number of countries, but these relationships vary by industry. Several studies find significant and large impacts of real exchange rate changes on net employment.(Branson and Love ,1988; Revenga ,1992; Dekle,1998; Leung and Yuen,2007; Hua,2007; Nucci and Pozzolo,2010). Others show that wage rates are typically more responsive to real exchange rate movements than employment (Goldberg and Tracy,2001; Campa and Goldberg ,2001). Few studies for China have explored the reverse causality of RMB exchange rate change effects on wage rates of Chinese industries, although several studies focus on analyzing and testing the significance of Balassa-Samuelson effects and implied wage rates adjustments for RMB real exchange rate change (McKinnon, 2005; McKinnon and Schnabl, 2006).

In this paper, we investigate both the impact of real exchange changes on labor market adjustments for individual Chinese manufacturing industries and the role of firm ownership characteristics. We use a panel data set covering 456 four digit industries over the period 2001 to 2009 to evaluate the effects of exchange rate changes on labor market behavior taking into account trends of RMB real exchange rate changes by industry before and after the reform of RMB exchange rate regime in July, 2005. Instead of using an aggregate RMB real effective exchange rate, we construct industry specific real effective exchange rates for 163 three digit industries over the period 2001 to 2009 which we apply to our four digit industry data. We specify dynamic employment and wage equations which capture the labor market adjustment process and duration of exchange rate changes so as to fully capture impacts of exchange rate movements on net employment and wage rates in both the short and long run.

We find that the RMB real exchange rate movements can have substantial effects on wage rates and net employment simultaneously. A 10\% appreciation of the RMB real exchange rate will cause effect in net employment about $4.1 \%$ to $5.3 \%$, and wage rates will also decline about $4 \%$ with the same appreciation. Our empirical results 
consistently show that the impact of RMB real exchange rate movements on wage and employment are systematically associated with export openness, overall import penetration and ownership characteristics of Chinese manufacturing industries. The magnitude of exchange rate movement effects on employment is also systematically related to the profit margins of manufacturing industries.

Our results suggest that the labor market behavior of private enterprises is less responsive to exchange rate fluctuations than SOEs. We also show that exchange rate movements can have larger effects on the labor market activity of SOEs and FIEs than private firms even after we control for the different profit margins of industries and the effects of exchange rate movements on labor market through other trade channels. Alexandre, et al.,(2010) have earlier noted that institutional factors can substantially influence the pass-through effects of exchange rate on domestic prices and output due to rigidities and different adjustment costs in labor market . Other studies of Chinese SOEs (Buckley, et al., 2007, Hale and Long, 2008) generally imply that the labor market activity of SOEs is less likely to be affected by real exchange rate shocks because wage determination and hiring by SOEs is less market based and more regulated by government policy. They also argue that SOEs are more likely to obtain financial support from the government and also more likely to be immune to price and exchange rate movements. Also, and in contrast to private enterprises, most SOEs have higher hiring or firing costs due to a higher percentage of formal employment and stronger labor market regulation. SOEs have lower average profit margins than private enterprises and FIEs also influence their labor market behavior. With low profit margins, SOEs are also more likely to be driven out of the market and experience bankruptcy with increased market competition ${ }^{(1)}$. Thus existing literature also suggests it is possible that real exchange rate appreciation can have more significant and larger effects on SOEs than Non-SOEs.

The paper is organized as follows. In section 2 we provide background and

\footnotetext{
(1) Summary statistics for the empirical sample we use later show that the average profit to sales margins of SOEs, private enterprises and FIEs in 456 four digit industries are $-1.67 \%, 5.32 \%$ and $6.05 \%$ respectively over the period 2001 to 2009; The market share of SOEs declines consistently from $18.4 \%$ in 2001 to $5.5 \%$ in 2009 , while the market share of private enterprise increases from $14.5 \%$ to $39.8 \%$. The market share of FIEs is relatively stable at around $30 \%$ over the same period.
} 
theoretical literature of the impacts of exchange rate change and labor market behavior in different countries and provide the specification used in our empirical model. Section 3 describes data, summary statistics and identification methods for the wage and employment equations. Section 4 presents empirical findings and discusses their possible implications. Section 5 provides conclusions.

\section{Background and Theoretical Literature`}

Existing literature does not provide conclusive evidence that real exchange rate change is associated with significant employment and wage adjustments but most available studies point in this direction. Branson and Love (1988) found that real exchange rate U.S. dollar appreciation would cause significant output and employment loss, and Revenga (1992), using three and four digit data for manufacturing industries of U.S. over the 1977-1987 period, also found that real exchange fluctuations can have significant impacts on employment and small but also significant impact on wage. Leung and Yuen (2007), using 21 manufacturing industries over the 1981-1997 period, explored the real exchange rate effects on Canadian labor market adjustment and also found evidence indicating that exchange movements have a substantial effects on employment and those effects increase with the trade openness, while the exchange rate change effects on real wages were estimated to be virtually zero. Using data for 29 Chinese provinces over the period 1993-2002, Hua (2007) explored the channels of effects for RMB real exchange rate change on employment of manufacturing industries and concluded that real exchange rate change had significant and substantial effects on employment.

Available studies also provide evidence that wage rates are more responsive to real exchange rate movements than employment and exchange rate movement impacts on net employment are smaller. Using two decades of two digit and four digit industry level data of U.S., Campa and Goldberg (2001) found exchange rates have significant and substantial effects on wage rates by industries, with the magnitude of wage effects rising as industries increased their export orientation and declining as imported input were intensively used. They did not find a pronounced impact of real exchange rate on 
net employment. Goldberg and Tracy(2001) also provide evidence that wage rates can be responsive to exchange movements during the job transitions by considering labor supply effects caused by the exchange rate fluctuations.

In our investigation of the effects of RMB appreciation on Chinese manufacturing employment and wages, we use a dynamic model which captures equilibrium employment and wage rate adjustments to real exchange rate shocks. Exchange rate fluctuations typically affect labor demand through two direct channels. Through the output channel, real exchange shocks change the relative price of domestic and foreign products and the level of domestic output and employment will change accordingly. They also have impact through the imported input or import competition channel. An appreciation (depreciation) of real exchange rate can decrease (increase) the cost of imported inputs and the price of imported final products. Depending on the degree of substitutability between domestic and imported goods, output and employment of domestic industries can be impacted in different ways.

The degree of responsiveness of output and employment to exchange rate shocks depends crucially on pass through effects of exchange rate change to domestic and foreign prices. Market structure matters because, in a competitive market, firms have limited ability to set prices and firms' output is affected by changes of foreign prices. Thus in a monopolistically competitive environment and with extensive production differentiation and market power, exchange rate shocks on output and employment can be partially offset by changed price setting. Trade orientation matters because exchange rates shocks and with them pass-through on to foreign demand are proportional to export openness. The pass-through on output and employment of exchange rate shocks through import channel depends on the degree of import penetration and substitutability between domestic products and imported goods.

The regulatory environment can also play an important role. If domestic industries are protected or supported by the government policies, relative prices, costs and the market share of domestic industries may not change with an exchange rate shock. Labor market regulations may also affect the speed of adjustment of employment to relative cost changes caused by exchange rate shocks. If costs of labor hiring or firing 
and output adjustment are large due to labor market regulation, firms will be reluctant to make large changes in employment in an uncertain duration. All these factors together influence the responsiveness of employment and wage rates to real exchange shocks.

The relationship between labor demand and exchange rates we use was originally developed by Klein, et al.(2003). They assume that in the presence of trade openness, exchange rate fluctuations are assumed to influence the output demand of industries according to the form,

$$
Q_{i t}^{D}=\delta_{i} Y_{i t}^{\beta} \prod_{j=1}^{k}\left(R E R_{j t}^{-\lambda \Omega_{i}} Y_{j t}^{* \beta \Omega_{i}}\right)^{\omega_{j t}^{i}}
$$

Where $Q_{i t}^{D}$ is the output demand for industry $i$ at time $t$, and $\delta_{i}$ is the demand shock facing industry $i$. Outputs of domestic industries are determined by income. $Y_{i t}$ is the total domestic factor return originating in the industry $i$ at time $t$, and $Y_{j t}^{*}$ is a multiplicative factor for each foreign country's income, which is negatively related to the bilateral real exchange rate $R E R_{j t}$. The pass-through effects of real exchange rates and foreign incomes on domestic output demand is assumed proportional to trade openness and other characteristics of each industry $\left(\Omega_{i}\right)$. Finally, the contribution of each trading partner is weighted by its share in total sector trade $\omega_{j t}^{i}$.

The cost function for each sector $i$ at time $t$ is,

$$
C_{i t}(W, R ; Q)=W_{i t}^{\alpha} R_{t}^{1-\alpha} Q_{i t}^{D}
$$

where $W_{i t}$ is the average wage of industry $i, R_{t}$ is the unit cost of non-labor input and $Q_{i t}^{D}$ is the domestic output of industry $i$.

Labor demand for industry $i$ is the partial derivative of the cost function with respect to wage rates (Shepard's Lemma), i.e.

$$
L_{i t}^{*}=\frac{\partial C_{i t}\left(W_{i t}, R_{t} ; Q_{i t}^{D}\right)}{\partial W_{i t}}=\alpha W_{i t}^{\alpha-1} R_{t}^{1-\alpha} Q_{i t}^{D}
$$

Using equations (1) and (3), we can derive the logarithm of optimal industry labor demand as,

$$
\begin{gathered}
L n L_{i t}^{*}=\operatorname{Ln} \alpha+\operatorname{Ln} \delta_{i}-(1-\alpha) \operatorname{Ln} R_{t}+\beta \operatorname{Ln} Y_{i t} \\
-\Omega_{i} \sum_{j=1}^{k} \omega_{j t}^{i} R E R_{j t}+\Omega_{i} \beta \sum_{j=1}^{k} \omega_{j t}^{i} Y_{j t}^{*}
\end{gathered}
$$


where $R E E R_{i t}=\sum_{j=1}^{k} \omega_{j t}^{i} R E R_{j t}$ is the trade weighted industry specific real exchange rate, and $Y_{i t}^{*}=\sum_{j=1}^{k} \omega_{j t}^{i} Y_{j t}$ is the trade weighted industry specific foreign income.

Current employment level is assumed to be best predictor of all future employment, and we assume an employment adjustment equation by industry given as,

$$
L n L_{i t}=\lambda L n L_{i t-1}+(1-\lambda) L n L_{i t}^{*}
$$

In this case, a general form for the labor demand is given by,

$$
L n L_{i t}=\lambda L n L_{i t-1}+(1-\lambda)\left(\begin{array}{c}
L n w_{i t}+(1-\alpha) L n R_{t}+\beta L n Y_{i t} \\
-\Omega_{i} R E E R_{i t}+\Omega_{i} \beta Y_{i t}^{*}
\end{array}\right)
$$

However, to evaluate how real exchange rate movements affect labor markets, we also need to consider the impact of real exchange rate shocks on wage adjustments and this introduces labor supply considerations. We assume labor supply for industry $i$ at time $t$ is

$$
L_{i t}=\left(\frac{W_{i t}}{W_{i t}^{* \varepsilon}}\right)^{\gamma}
$$

where $W_{i t}^{*}$ is the average wage of industries alternative to industry $i, \gamma$ is a measure of the labor supply elasticity $(\gamma>0)$ and $\varepsilon$ is the cross-elasticity of labor supply with respect to wage rates between sector $i$ and other industries.

To capture the wage spillover effects across different industries through labor supply channels, we use average wage rates of other four digit industries to represent the prevailing wage of industries alternative to industry $i^{\mathbb{1}}$.Equating labor demand and labor supply equations, we can derive both the employment and wages equation in equilibrium for industry space $i$. We use industry dummies to control for time invariant fixed effects, $\left(\operatorname{Ln} \delta_{i}\right)$ and time dummies to control for other macroeconomic factors $\left(L n R_{t}\right)$. Taking into account dynamic impacts of exchange rate fluctuations on labor market; we also control the lagged variables of real exchange rate in our empirical equations. The reduced form of the wage and employment equations by

\footnotetext{
(1) The average wage for industries alternative to industry $i$ is calculated as, $W_{i t}^{*}=\frac{S T W_{i t}-T W_{i t}}{S T L_{i t}-T L_{i t}}$, where $S T W_{i t}$ and $S T L_{i t}$ represent the sum of wage rates and employment of all four digit industries respectively, and $T W_{i t}$ and $T L_{i t}$ represent the wage rates and employment in each industry $i$.
} 
industry can be written as,

$$
\begin{aligned}
& L n L_{i t}=\alpha_{0}+\alpha_{1} L n Y_{i t}+\alpha_{2} \Omega_{i} L n Y_{i t}^{*}+\alpha_{3} L n W_{i t}^{*}+\alpha_{4} \Omega_{i}\left(\operatorname{LnREER_{it}}+\operatorname{LnREER_{it-1}}\right) \\
& +\alpha_{5} L n L_{i t-1}+f_{i}+f_{t} \\
& L n W_{i t}=\delta_{0}+\delta_{1} L n Y_{i t}+\delta_{2} \Omega_{i} L n Y_{i t}^{*}+\delta_{3} L n W_{i t}^{*}+\delta_{4} \Omega_{i}\left(\operatorname{LnREER_{it}}+\operatorname{LnREER}_{i t-1}\right) \\
& +\delta_{5} L_{n} L_{i t-1}+f_{i}+f_{t}
\end{aligned}
$$

where $f_{i}$ and $f_{t}$ represent individual and time fixed effects in individual industries. The impacts of real exchange rate and foreign income changes on labor market behavior depend on pass-through effects. In our analysis above, $\Omega_{i}$ is determined by many factors, including export openness, imported input and imported final product penetration rates, the market structure and ownership characteristics of the industries .

To analyze whether real exchange rate effects on labor market are systematically related to these factors, we specify $\Omega_{i}=\Omega_{i}\left(E X S_{i}, I M S_{i}, P R O_{i}, O W N_{i}\right)$ based on the analysis above, where $E X S_{i}$ and $I M S_{i}$ represent average export openness and overall import penetration rates over the period 2001 to 2009 for industry $i$ respectively ${ }^{(1)}$, and where $P R O_{i}$ and $O W N_{i}$ represent average profit margins and ownership characteristics of industries over the same period.

We use these two variables to investigate linkage between exchange rate change effects and labor markets from market structure and institutional factors of labor market. Taking into account heterogeneity issues in estimation, we estimate differenced equations instead of level equations to evaluate these effects.

Our final wage and employment equations therefore reduce to,

$$
\begin{aligned}
& \Delta L n L_{i t}=\beta_{0}+\beta_{1} \Delta L n Y_{i t}+\beta_{2} T O_{i} * \Delta L n Y_{i t}^{*}+\beta_{3} \Delta L n W_{i t}^{*}+\Omega_{i}\left(\begin{array}{c}
E X S_{i}, I M S_{i}, \\
P R O_{i}, O W N_{i}
\end{array}\right) * \\
& \left(\beta_{4} \Delta L n R E E R_{i t}+\beta_{5} \Delta L n R E E R_{i t-1}\right)+\beta_{6} \Delta L n L_{i t-1}+v_{t}+\omega_{i t} \\
& \Delta L n W_{i t}=\gamma_{0}+\gamma_{1} \Delta L n Y_{i t}+\gamma_{2} T O_{i} * \Delta L n Y_{i t}^{*}+\gamma_{3} \Delta L n W_{i t}^{*}+\Omega_{i}\left(\begin{array}{c}
E X S_{i}, I M S_{i}, \\
P R O_{i}, O W N_{i}
\end{array}\right) * \\
& \left(\gamma_{4} \Delta L n R E E R_{i t}+\gamma_{5} \Delta L n R E E R_{i t-1}\right)+\gamma_{6} \Delta L n L_{i t-1}+v_{t}+\sigma_{i t}
\end{aligned}
$$

\footnotetext{
(1) To capture dynamic effects of real exchange rate changes on labor market, we control current and lagged interactive variable of exchange rate and trade dependence simultaneously. To overcome the simultaneity issue of exchange rate and trade dependence and the random movements of trade dependence in different periods, we use average export openness and average import penetration rates instead of time variant variables for trade dependence.
} 
where $T O_{i}$ is the average trade openness of the specific industry ${ }^{(1)} . \omega_{i t}$ and $\sigma_{i t}$ are the residual errors of estimation for wage and employment equations respectively, and $v_{t}$ is the time dummy used to control for other macroeconomic factors.

\section{Data , Summary Statistics and Model Identification}

\subsection{Data and summary statistics}

We use industry level data covering 456 four digit manufacturing industries over the time period of 2001 to 2009. Data are drawn from the industrial database of China supported by National Bureau of Statistics of China. The database provides over 65 financial variables for each industry, including value added in production, export sales, wage rates and employment levels, and the ratio of net profits of sales. To link to the industry level trade data between China and its 41 bilateral trading partners, we construct a correspondence between HS four digit codes for 1250 trade products and industry codes for 175 three digit manufacturing industries in China ${ }^{2}$. Bilateral trade data classified at a HS 4 digit product level between China and 41 trading partners over the period of 1999 to 2009 are drawn from International Trade Statistics (ITS) and COMTRADE database of United Nations. Real GDP data for 41 trading partners and the CPI index and bilateral nominal exchange rate for China and 41 trading partners are all drawn from International Financial Statistics, IMF. To investigate the relationship between competitive market structures of industries and real exchange rate effects on labor markets, we divide the sample into low price over cost markup industries and high price over cost markup industries using data to average profit margins of industries over the period 2001 to 2009.

Table1 presents summary statistics for our sample, including indices of total employment, average wage paid, export sales and profit margins for different ownership industries. These descriptive statistics indicate that average profit margins

\footnotetext{
(1) This paper investigate the relationship between exchange rate and labor market adjustments, and to simplify model identification and estimation, we here only estimate the interactive effects of foreign income and overall trade openness on labor markets and do not investigate the interactive effects of foreign income and other characteristic of industries.

(2) The correspondence is constructed referring to the correspondence table of HS, ISIC (Revision 4) and the classification code (Revision 2002) for Chinese manufacturing industries
} 
of SOEs are lower than for Non-SOEs over the whole period, and that export values and export openness for FIEs are higher than for SOEs and private enterprises.

TABLE 1 HERE

The figures below show selected three digit industry specific real exchange rates of RMB from the year 2001 to 2009. There is substantial heterogeneity in the behavior of these real exchange rates at industry level. Most industry specific real exchange rates of RMB depreciate continuously from 2001 to 2004 and appreciate overall from 2005 to 2009. However, the fluctuation of these real exchange rates varies substantially both within and across industries. The real exchange rate variation within chemical industries is smaller than for food and sport article industries, while real exchange rate movements for specific sectors are different from most other sectors.

\section{FIGURES HERE}

\subsection{Identification Methods for Wage and Employment Equations.}

For the wage and employment equations specified in section 2, we cannot use OLS and random estimators because the predetermined variables in employment equations and other endogenous variables in both wage and employment equations are correlated with the individual effects $f_{i}$. The fixed effect estimator can eliminate the individual effects by transforming data into deviations from the within group mean, but it is still biased because the group mean of predetermined and other endogenous variable is still correlated with mean of the error terms. The generalized moment method (GMM) and Panel IV (2SLS/GMM) estimators are frequently adopted measures to identify the dynamic panel data model and to control for the endogeneity issues.

We use two-step system GMM estimators (Arellano and Bover, 1995; Blundell and Bond, 1998) instead of difference GMM estimators to identify our dynamic employment equation. We also control for the adjustment processes of employment and other endogenous variables. Wage equations are identified using both Panel IV (2SLS) and Panel IV (GMM) estimators to control for endogeneity. As endogeneity tests of variables when applying the Panel IV estimators, two variables $\left(\Delta L n Y_{i t}\right.$ and $\left.\Delta L n W_{i t}^{*}\right)$ are set as endogenous variables both in the employment and 
wage equations. The lagged level and lagged difference endogenous variables and other exogenous variables are then set as the instruments for those endogenous variables.

\section{Empirical Results}

\subsection{Trade Openness, Profit Margins and Real Exchange Rate Effects on Employment}

We first report results on the links between real exchange rate changes and employment taking into account export openness, overall import penetration and profit margins by industries. These are reported in Table2.

In column 1 of table 2, employment equations are estimated using the full sample and coefficients indicate that the adjustment process of labor market is significant and the previous employment levels have positive and significant effects on current net employment. Both the domestic and foreign income have significant and positive effects on net employment. The foreign income effects on employment are also systematically related to the average trade openness of industries. The coefficient of the wage rate for the alternative industries is also positively significant, which fits the theoretical prediction that the relative demand of labor will increase in the specific sector when the wage rates of other sectors increase.

Estimation results also show that exchange rate change effects on employment are crucially dependent on the export openness. All interactive variables of export openness and exchange rates are negatively significant at a $1 \%$ level. The real exchange rate change has substantial effects on net employment in highly export oriented sectors, while interactive variables of import penetration and exchange rate are also significant. The impact of exchange rate movements on employment through overall import penetration channels is smaller. This is because the relationship between domestic output and imported inputs is more likely to be complimentary, while the relationship between domestic output and imported final products is substitutable and competitive. The impacts of exchange rate movements on employment through both import input and import competition mechanisms (overall import penetration) seem minimal due to the offsetting forces. According to the estimated coefficients in column 
1, a $10 \%$ appreciation of $\mathrm{RMB}$ real exchange rate will result in a $4.15 \%$ reduction in overall net employment in Chinese manufacturing industries in the short run, while this impact could reach 5.32\% in the long run after controlling for other factors.

To check whether profit margins can significantly influence the pass-through effects of exchange rate movements on employment, we also divide the sample into two subsamples based on average profit margins of industries. The results, using the two separate subsamples, are reported in columns 2 and 3 of Table2. The coefficients of interactive variables indicate that real exchange rate movements can have significant effects on high profit margin sectors, through the export openness channel, while the exchange rate change can have significant and larger effects on low profit margin sectors through both export openness and import penetration channels.

The coefficient of lagged employment variable is negative and insignificant in high profit margin sectors, while the coefficient of the same variable is positive in low profit margin sectors. The different results for this coefficient in different sectors imply that the magnitude of employment adjustments can be larger in low profit margin sectors. According to the estimation results reported in columns 2 and 3 of Table 2, a $10 \%$ appreciation in the real exchange rate will cause net employment level in high profit margin sectors to drop by about $2.3 \%$, while in the low profit margin sectors, a $10 \%$ appreciation of real exchange rate will result in a $4.4 \%$ reduction in net employment in the short run. Costs will increase by around $11.8 \%$ due to substantial employment adjustments in the long run.

To check the robustness of the results reported in columns 2 and 3, the interactive variables of profit margins and real exchange rate are also estimated using the full data sample after controlling for all other interactive variables in column 4 . The coefficients of interactive variables in column 4 show that the impacts of real exchange rate movements on employment are systematically associated with the profit margins of industries. The negative impact of exchange rate appreciation on employment decreases with the growth of profit margins of the industries, consistent with the empirical results shown in column 2 and 3.

Taking into account the possible endogeneity of interactive variables, we also 
estimate the lagged interactive variables in column 5 after controlling for other variables. The coefficients and significance of lagged interactive variables in column 5 does not change much compared to those estimation results in columns 1 and 4 . These show that the impacts of RMB real exchange rate movements on employment are systematically related to export openness, import penetration and profit margins of Chinese manufacturing industries.

\section{TABLE 2 HERE}

\subsection{Ownership Characteristics and Real Exchange Rate Effects on Employment}

To analyze whether institutional factors and labor market regulation can influence real exchange rate change effects on industrial employment, we also investigate the link between exchange rate movement effects on employment and ownership characteristics of manufacturing industries. We use the shares of production by SOEs, private enterprises, and FIEs with industries to reflect the ownership structure of different industries. Exchange rate change effects on net employment of different ownership enterprises are also evaluated using the interactive variable of exchange rates and the shares of production of different ownership enterprises.

Results are reported in Table 3. In columns 1 and 2 of Table 3, the coefficients of interactive variables of exchange rates and shares of SOEs are all negatively significant at 5\%, even after controlling for the pass-through effects of exchange rate changes on employment through export openness, import penetration channel and for different profit margins industries. These results also indicate the negative impacts of exchange rate appreciation on employment increase with an increased share of SOEs in Chinese manufacturing industries.

In columns 3 and 4, the coefficients of interactive variables of exchange rates and shares of private enterprises are all positively significant at the5\% level after controlling for all other variables as in columns 1 and 2. These results also imply that the negative impact of exchange rate appreciation on employment decreases with an increased share of private enterprise. To further check the robustness of the results in columns 1 to 4, we also control all the interactive variables for exchange rate and shares of different enterprises in column 5. Results in column 5 remain consistent with 
the results reported in columns 1 to 4 .

In column 6, we investigate the relationship between exchange rate effects on net employment and shares of FIEs. The coefficients for the interactive variables of exchange rates and shares of FIEs are all negatively significant at a 5\% level ${ }^{(1)}$ Results show that the negative impact of RMB exchange rate appreciation on net employment also increases with the higher shares of FIEs in manufacturing industries. All the above regression results above imply that the net employment of SOEs and FIEs is more responsive to RMB real exchange movements than is true for private enterprises, and that the impacts of RMB real exchange rates on net employment are also systematically associated with the ownership characteristic of Chinese industries.

It is understandable that the net employment of FIEs is more responsive to the RMB real exchange rate because most FIEs in Chinese manufacturing industries are concentrated in export oriented sectors. The average export openness for FIEs is also much higher than for SOEs and private enterprises. The magnitude of exchange rate movements on net employment of FIEs through export channel can also be more substantial. However, it is contrary to the prediction that private enterprises are more responsive to exchange rate movements than SOEs due to low percentages of formal employment for private enterprises and stronger rigidities or regulations in labor markets for SOEs.

A possible explanation for these results is that the marketing performance and efficiency and average profit margins of SOEs in manufacturing industries are lower than those of private enterprises. SOEs have less price-setting ability and less flexibility to adjust their output structure to counteract the negative effects of exchange rate movements. SOEs are also more likely to be driven out of the market and cause a substantial loss of net employment with growing market competition due to exchange rate appreciation. Thus, the overall impact of exchange rate movements on labor market behavior of SOEs can be more substantial than for private enterprises in the long run.

\footnotetext{
(1) In column 6 of table 3, the interactive variables of export openness and real exchange rate are not controlled due to the multicollinearity issues. The correlation coefficient between the share of FIEs and export openness is over 0.85 .
} 


\section{TABLE 3 HERE}

\subsection{Trade Openness, Profit Margins and Real Exchange Rate Effects on Wage Rates}

We next evaluate the impact of RMB real exchange rate movements on wage rates of Chinese manufacturing industries. The wage equations specified in section 3 are identified using Panel IV fixed effect estimators and results are reported in Table 4.

In column 1 of table 4 , we report results investigating the link between real exchange rate movement effects on wage rates and average export openness, overall import penetration and profit margins of manufacturing industries. Results indicate that domestic and foreign incomes can both have positive and significant effects on wage rates, and that pass-through effects of foreign income on wage rates are systematically associated with trade dependence by industry; growth on average wage rates in alternative industries can also have positive and significant effects on specific industry implying that there are positive and significant wage spillovers across different industries.

Coefficients of the interactive variables of export openness and real exchange rates are all negatively significant, and the coefficients of lagged interactive variables of import penetration rates and real exchange rates are also negative and significant. Results for these interactive variables consistently show that the impacts of real exchange rate movements on wage rates are systematically associated with export openness and import penetration by industry. The negative impacts of real exchange rate appreciation strengthen with the expansion of export openness and import penetration rates, while exchange rate change effects on wage rates are more substantial through export openness than import penetration channels. According to the estimated coefficients for interactive variables, a 10\% appreciation of RMB real exchange rate will cause average wage rates in Chinese manufacturing industries to drop by 3.8\% after controlling for other variables. Real exchange rate movements can thus have substantial effects on wage rates, and the mechanisms and channels of exchange rate change effect on wage rates and employment are similar.

In columns 2 and 3 of table 4, we report results which explore the different impacts of exchange rate movements on wage rates in low and high profit margins 
industries respectively. These results show that exchange rate movements can have significant impacts on wage rates through both export openness and import penetration mechanisms in high profit margin industries, while exchange rate change effects on low profit margin industries take place only through export openness. The impact of exchange rates on wage rates in high profit margin industries is more substantial than the impact in low profit margin industries. A 10\% appreciation of real exchange rates will cause average wage rates in high profit margin industries to drop by $4.5 \%$ while average wage rate decline in low profit margin industries by $2.4 \%$.

In column 4 of table 4 , we use the interactive variables of average profit margins of industries and real exchange rate to check whether the impacts of exchange rate movements on wage rates are also systematically related to the profit margins of manufacturing industries. The interactive variables of exchange rates and profit margins are all insignificant. There is no clear evidence that exchange rate movement effects on wage rates depend on the profit margins of the industries.

To further check the robustness of the results in columns 1 to 4, we also use the more efficient feasible GMM estimators to identify the wage equations. The results in column 5 and 6 are similar to those results in columns 1 and 4. All these results consistently show that exchange rate movements can have substantial effects on wage rates adjustment, and the impacts of exchange rate change on wage rate are also systematically associated with export openness and overall import penetration rates of industries.

\section{TABLE 4 HERE}

\subsection{Ownership Characteristics and Real Exchange Rate Effects on Wage Rates}

Institutional factors and labor market regulations are also likely to influence the responsiveness of wage rates to exchange rate fluctuations. We thus also investigate the link between exchange rate movement effects on wage rates with the ownership characteristics of industries. Results are reported in Table 5. In column 1 of Table5, the interactive variables of exchange rates and shares of SOEs are insignificant after controlling for other variables. Result also shows that there is no significant difference in impacts of exchange rate movements on wages rates between SOEs and overall 
enterprises. In column 2, interactive variables of exchange rates and shares of private enterprises are all positively significant. Result indicates that the responsiveness of wage rates to exchange rate movements declines with the increase share of private enterprises. The wage rates of private enterprises are less sensitive to real exchange rate movements than is true for other enterprises. In column 3, interactive variables of exchange rates and shares of FIEs are all negatively significant after controlling for all other variables. Empirical results indicate that wage rates of FIEs are more responsive to real exchange rates than is true for other enterprises. The negative effects of real exchange rate appreciation on wage rates thus increase with the increased share of FIEs.

To take into account the possible reverse causality of wage rates change and real exchange rate movements (Balassa-Samuelson effects), we can only control and estimate the lagged interactive variables and other variables . The results in column 4 and 5 still indicate a systematic relationship between the impacts of exchange rate movements on wage rates and the ownership characteristic of the industries. The negative impacts of exchange rate appreciation on wage rates increase with the growth share of FIEs which decline with the growth share of private enterprises. In column 6, we control all the interactive variables simultaneously in the wage equations to further check the robustness. The results in column 6 indicate the same conclusion as for the results in columns 1 to 5 .

The above results and also those in Table 3 all consistently show that the employment and wage rates of FIEs and SOEs are both more responsive to exchange rate movements than is true for private enterprises. Possible reasons are that, FIEs are more profit and export oriented; FIEs are more sensitive to the exchange rate fluctuations and more likely to adjustment the wage rates and employment level to counteract the negative effects of exchange rate shocks and keep relative stable profit margins of their operation, while private enterprises are more domestic market oriented than FIEs and they are more willing to keep a relative stable labor market and adjust profit margins in response to the exchange rate shocks. Due to the lower efficiency and performance, SOEs also have relatively little room to adjust their profit margins and 
are more likely to go bankrupt with an increase in exchange rate fluctuations in the long run. The magnitudes of labor market adjustments of SOEs are thus likely to be greater than for private enterprises.

\section{TABLE 5 HERE}

\section{Conclusion}

This study investigates the effects of possible RMB appreciation on both employment and wages in China, and also the link between exchange rate movement effects on labor market and ownership characteristics of the industries. Using a representative sample covering 456 four digit Chinese manufacturing industries over the period of 2001 to 2009, we find that the impacts of exchange rate change on labor market crucially depends on the ownership characteristics of the industries. The labor market behavior of SOEs and FIEs are more responsive to exchange rate movements than is true for private enterprises. This is contrary to the common belief that the less export oriented and less market based SOEs are not more responsive to real exchange rate fluctuations than private enterprises. It appears that FIEs are more likely to adjust wage and employment levels to counteract negative effects of exchange rate appreciations on their profit margins, while private enterprises tends to adjust their profit margins to keep a relative stable labor market. SOEs are more prone to be driven out of the market with a real exchange rate appreciation.

In contrast to previous studies, we also find that the RMB real exchange rate movements can have substantial effects on wage rates and net employment simultaneously. A 10\% appreciation of the RMB real exchange rate will cause effect in net employment about $4.1 \%$ to $5.3 \%$, and wage rates will also decline about $4 \%$ with the same appreciation. Our empirical results consistently show that the impact of RMB real exchange rate movements on wage and employment are systematically associated with export openness, overall import penetration and ownership characteristics of Chinese manufacturing industries. The magnitude of exchange rate movement effects on employment is also systematically related to the profit margins of manufacturing industries. 
Table 1 Summary Statistics for Chinese Manufacturing Industries (2001-2009)

\begin{tabular}{|c|c|c|c|c|c|}
\hline Index & Ownership & Obersevations & MEAN & MIN & MAX \\
\hline \multirow{3}{*}{$\begin{array}{c}\text { Employment } \\
\text { (unit:1000 person) }\end{array}$} & SOE & 3961 & 21198 & 0 & 2539443 \\
\hline & Private & 4126 & 36665 & 0 & 1646390 \\
\hline & Foreign & 4080 & 38583 & 0 & 2128701 \\
\hline \multirow{3}{*}{$\begin{array}{c}\text { Average Wage } \\
\text { (Unit: } 1000 \mathrm{RMB} / \mathrm{PERSON})\end{array}$} & SOE & 3766 & 16.29 & 0 & 133.21 \\
\hline & Private & 4087 & 13.32 & 0.33 & 80.54 \\
\hline & Foreign & 4007 & 22.34 & 1.46 & 1847.75 \\
\hline \multirow{3}{*}{$\begin{array}{l}\text { Total production } \\
\text { (Unit:1000RMB) }\end{array}$} & SOE & 3961 & 6226239 & 0 & $5.77 \mathrm{E}+08$ \\
\hline & Private & 4126 & $1.34 \mathrm{E}+07$ & 0 & $7.01 \mathrm{E}+08$ \\
\hline & Foreign & 4080 & $1.77 \mathrm{E}+07$ & 0 & $9.41 \mathrm{E}+08$ \\
\hline \multirow{3}{*}{$\begin{array}{c}\text { Export Value } \\
\text { (Unit:1000RMB) }\end{array}$} & SOE & 3961 & 412585 & 0 & $8.71 \mathrm{E}+07$ \\
\hline & Private & 4126 & 1229004 & 0 & $8.27 \mathrm{E}+07$ \\
\hline & Foreign & 4080 & 7096389 & 0 & $7.24 \mathrm{E}+08$ \\
\hline \multirow{3}{*}{$\begin{array}{l}\text { Profit rate } \\
\text { (Unit \%) }\end{array}$} & SOE & 4165 & -1.67 & -241.51 & 58.39 \\
\hline & Private & 4164 & 5.32 & -9.9 & 19.04 \\
\hline & Foreign & 4145 & 6.05 & -16.5 & 48.49 \\
\hline \multirow{3}{*}{$\begin{array}{l}\text { Export Openness } \\
\text { (Unit \%) }\end{array}$} & SOE & 4125 & 9.72 & 0 & 78.43 \\
\hline & Private & 4158 & 12.58 & 0 & 63.87 \\
\hline & Foreign & 4142 & 34.97 & 0 & 89.23 \\
\hline $\begin{array}{l}\text { Import Value } \\
\text { (Unit:1000RMB) }\end{array}$ & ALL & 3894 & $2.64 \mathrm{E}+07$ & 0 & $6.78 E+08$ \\
\hline $\begin{array}{l}\text { Import penetration } \\
\text { (Unit \%) }\end{array}$ & ALL & 3894 & 41.74 & 0 & 99.81 \\
\hline $\begin{array}{l}\text { Real Effective Exchange Rate } \\
\text { (Year2005=100) }\end{array}$ & ALL & 3883 & 102.12 & 60.68 & 216.43 \\
\hline
\end{tabular}

Source: Industrial Database, National Bureau of Statistics of China 
Figures Movements in Industry Specific RMB Real Exchange Rates, China, 2001-2009
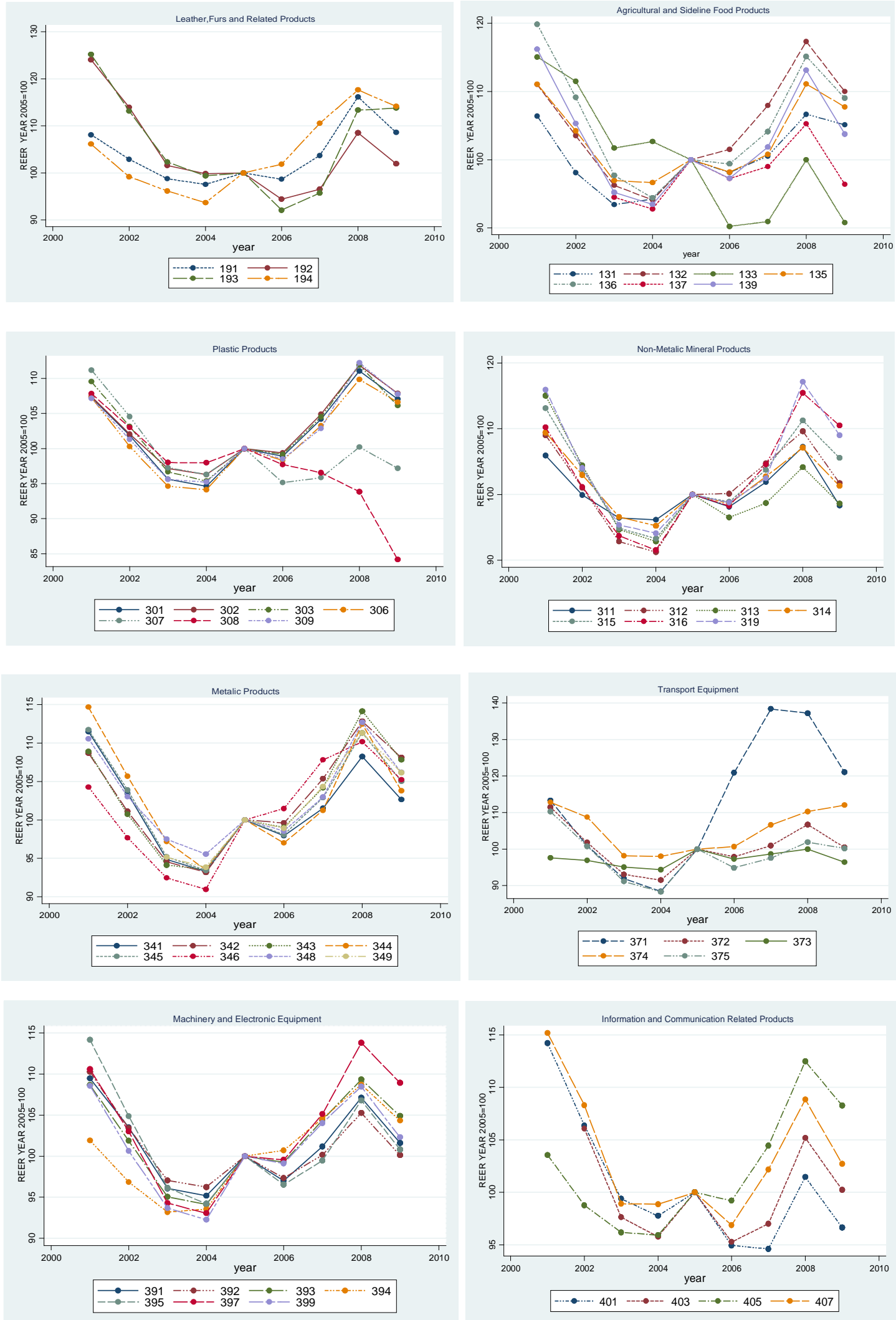

Source: Caculation using data from International Trade Statisitics, Comtrade Database of U.N. and International Financial Statistics of IMF. 
Table 2 Trade Openness, Profit Margins and Real Exchange Rate Movement Effects on Industrial Employment (Dependent Variable: $\Delta L n L_{i t}$ )

\begin{tabular}{|c|c|c|c|c|c|}
\hline \multirow{2}{*}{ Independent Variables } & (1) & (2) & (3) & (4) & (5) \\
\hline & ALL Ind. & High Pro. & Low Pro. & ALL Ind. & ALL Ind. \\
\hline \multirow[t]{2}{*}{$\Delta L n L_{i t-1}$} & $0.1127 * * *$ & -0.0248 & $0.3890 * * *$ & $0.1152 * * *$ & $0.1165^{* * *}$ \\
\hline & $(0.034)$ & $(0.123)$ & $(0.137)$ & $(0.034)$ & $(0.037)$ \\
\hline \multirow[t]{2}{*}{$\Delta \operatorname{Ln} Y_{i t}$} & $0.3363 * * *$ & $0.2816^{*}$ & 0.1761 & $0.3413 * * *$ & $0.3664 * * *$ \\
\hline & $(0.071)$ & $(0.150)$ & $(0.117)$ & $(0.072)$ & $(0.075)$ \\
\hline \multirow[t]{2}{*}{$T O_{i} * \Delta \operatorname{Ln} Y_{i t}^{*}$} & $1.4364 * *$ & 1.8263 & $2.1728 * * *$ & $1.5432 * *$ & 0.581 \\
\hline & $(0.682)$ & (1.329) & $(0.807)$ & $(0.670)$ & $(0.667)$ \\
\hline \multirow[t]{2}{*}{$\Delta$ LnWage $_{i t}^{*}$} & $0.2981^{* *}$ & 0.2768 & 0.089 & $0.2105 *$ & $0.2517 * *$ \\
\hline & $(0.117)$ & $(0.177)$ & $(0.135)$ & $(0.117)$ & $(0.120)$ \\
\hline \multirow[t]{2}{*}{$E X S_{i} * \Delta L n R E E R_{i t}$} & $-1.3077^{* * *}$ & $-1.3850 * * *$ & $-0.9236 * *$ & $-1.3795^{* * *}$ & \\
\hline & $(0.265)$ & $(0.511)$ & $(0.396)$ & $(0.257)$ & \\
\hline \multirow[t]{2}{*}{$E X S_{i} * \Delta L n R E E R_{i t-1}$} & $-1.1390 * * *$ & -0.628 & $-1.0592 * *$ & $-1.2043^{* * *}$ & $-1.0458 * * *$ \\
\hline & $(0.316)$ & $(0.544)$ & $(0.456)$ & $(0.300)$ & $(0.312)$ \\
\hline \multirow[t]{2}{*}{$I M S_{i} * \Delta L n R E E R_{i t}$} & $-0.3214 *$ & -0.3388 & $-0.5032 * *$ & $-0.3688 * *$ & \\
\hline & $(0.173)$ & $(0.288)$ & $(0.235)$ & $(0.180)$ & \\
\hline \multirow[t]{2}{*}{$I M S_{i} * \triangle L n R E E R_{i t-1}$} & $0.4503^{* * *}$ & 0.4002 & 0.2654 & $0.3723^{* *}$ & $0.3969 * *$ \\
\hline & $(0.174)$ & $(0.312)$ & $(0.278)$ & $(0.187)$ & $(0.188)$ \\
\hline \multirow[t]{2}{*}{$P R O_{i} * \triangle \operatorname{LnREE} R_{i t}$} & & & & 0.003 & \\
\hline & & & & $(0.008)$ & \\
\hline \multirow[t]{2}{*}{$P R O_{i} * \triangle L n R E E R_{i t-1}$} & & & & $0.0160 *$ & $0.0185^{*}$ \\
\hline & & & & $(0.009)$ & $(0.011)$ \\
\hline \multicolumn{6}{|l|}{ Net $\triangle L n R E E R_{i t}$} \\
\hline Short Run Effects & -0.415 & -0.226 & -0.440 & & \\
\hline Long Run Effects & -0.532 & -0.226 & -1.184 & & \\
\hline Observations & 2,961 & 1,475 & 1,486 & 2,961 & 2,961 \\
\hline Number of Ind. & 456 & 229 & 227 & 456 & 456 \\
\hline Time Dummy & Yes & Yes & Yes & Yes & Yes \\
\hline Autocorrelation Test & 0.647 & 0.439 & 0.769 & 0.663 & 0.774 \\
\hline \multirow{2}{*}{\multicolumn{2}{|c|}{$\begin{array}{l}\text { Over Identification Test } \\
\text { Hansen J(P_value) } \\
\text { Instrument Subset Exgenoeity Test: }\end{array}$}} & 0.431 & 0.382 & 0.573 & 0.35 \\
\hline & & & & & \\
\hline Hansen Test(P_value) & 0.741 & 0.412 & 0.271 & 0.726 & 0.634 \\
\hline Difference(P_value) & 0.095 & 0.452 & 0.618 & 0.190 & 0.071 \\
\hline
\end{tabular}

Notes: The employment equations are all identified using the two-step system Generalized Moment Method estimators. $\Delta L n L_{i t-1}, \Delta L n Y_{i t}$ and $\Delta L n W a g e_{i t}^{*}$ are set as endogenous variables based on the panel IV endogenous tests. Robust standard errors are computed below the coefficients to correct the downward bias of standard errors; ****, $(* *, *)$ indicates rejection of null hypothesis is significant at $1 \%,(5 \%, 10 \%)$. 
Table 3 Ownership Characteristics and Real Exchange Rate Movement Effects on Industrial Employment (Dependent Variable: $\Delta L n L_{i t}$ )

\begin{tabular}{|c|c|c|c|c|c|c|}
\hline Independent Variables & (1) & $(2)$ & (3) & (4) & (5) & $(6)$ \\
\hline$\Delta L n L_{i t-1}$ & $\begin{array}{c}0.1135^{* * *} \\
(0.034)\end{array}$ & $\begin{array}{c}0.1142 * * * \\
(0.035)\end{array}$ & $\begin{array}{c}0.1118 * * * \\
(0.034)\end{array}$ & $\begin{array}{c}0.1129 * * * \\
(0.034)\end{array}$ & $\begin{array}{c}0.1110^{* * *} \\
(0.034)\end{array}$ & $\begin{array}{c}0.0971 * * * \\
(0.034)\end{array}$ \\
\hline$\Delta \operatorname{Ln} Y_{i t}$ & $\begin{array}{c}0.3299 * * * \\
(0.072)\end{array}$ & $\begin{array}{c}0.3264 * * * \\
(0.072)\end{array}$ & $\begin{array}{c}0.3483 * * * \\
(0.071)\end{array}$ & $\begin{array}{c}0.3450 * * * \\
(0.071)\end{array}$ & $\begin{array}{c}0.3300 * * * \\
(0.072)\end{array}$ & $\begin{array}{c}0.3612 * * * \\
(0.085)\end{array}$ \\
\hline$T O_{i} * \Delta \operatorname{Ln} Y_{i t}^{*}$ & $\begin{array}{c}1.5005^{* *} \\
(0.695)\end{array}$ & $\begin{array}{c}1.5754 * * \\
(0.685)\end{array}$ & $\begin{array}{c}1.3940 * * \\
(0.697)\end{array}$ & $\begin{array}{c}1.5036^{* *} \\
(0.688)\end{array}$ & $\begin{array}{c}1.5315^{* *} \\
(0.705)\end{array}$ & $\begin{array}{c}1.9551^{* * *} \\
(0.514)\end{array}$ \\
\hline$\Delta \operatorname{LnWage_{it}^{*}}$ & $\begin{array}{c}0.2932 * * \\
(0.119)\end{array}$ & $\begin{array}{c}0.2150 * \\
(0.123)\end{array}$ & $\begin{array}{c}0.2499 * * \\
(0.114)\end{array}$ & $\begin{array}{l}0.1881 \\
(0.118)\end{array}$ & $\begin{array}{c}0.1899 \\
(0.123)\end{array}$ & $\begin{array}{c}0.1925 * \\
(0.108)\end{array}$ \\
\hline$E X S_{i} * \Delta \operatorname{LnREER_{it}}$ & $\begin{array}{c}-1.3588^{* * *} \\
(0.269)\end{array}$ & $\begin{array}{c}-1.4687^{* * *} \\
(0.260)\end{array}$ & $\begin{array}{c}-1.4197^{* * *} \\
(0.266)\end{array}$ & $\begin{array}{c}-1.4292^{* * *} \\
(0.265)\end{array}$ & $\begin{array}{c}-1.4957^{* * *} \\
(0.271)\end{array}$ & \\
\hline$E X S_{i} * \Delta L n R E E R_{i t-1}$ & $\begin{array}{c}-1.0986^{* * *} \\
(0.311)\end{array}$ & $\begin{array}{c}-1.2268 * * * \\
(0.299)\end{array}$ & $\begin{array}{c}-1.3888 * * * \\
(0.313)\end{array}$ & $\begin{array}{c}-1.3735^{* * *} \\
(0.312)\end{array}$ & $\begin{array}{c}-1.3918 * * * \\
(0.309)\end{array}$ & \\
\hline$I M S_{i} * \Delta \operatorname{LnREER_{it}}$ & $\begin{array}{l}-0.2907 \\
(0.177)\end{array}$ & $\begin{array}{c}-0.3582 * * \\
(0.181)\end{array}$ & $\begin{array}{c}-0.3728 * * \\
(0.169)\end{array}$ & $\begin{array}{c}-0.3899 * * \\
(0.177)\end{array}$ & $\begin{array}{c}-0.3734^{* *} \\
(0.178)\end{array}$ & $\begin{array}{c}-0.4652 * * \\
(0.192)\end{array}$ \\
\hline$I M S_{i} * \Delta \operatorname{LnREER_{it-1}}$ & $\begin{array}{c}0.4660^{* *} \\
(0.183)\end{array}$ & $\begin{array}{c}0.4155^{* *} \\
(0.190)\end{array}$ & $\begin{array}{c}0.3622 * * \\
(0.176)\end{array}$ & $\begin{array}{c}0.3436 * \\
(0.186)\end{array}$ & $\begin{array}{c}0.3809 * * \\
(0.188)\end{array}$ & $\begin{array}{l}0.3373 \\
(0.224)\end{array}$ \\
\hline$P R O_{i} * \triangle \operatorname{LnREER_{it}}$ & & $\begin{array}{c}0.0112 \\
(0.009)\end{array}$ & & $\begin{array}{l}0.0009 \\
(0.009)\end{array}$ & $\begin{array}{l}0.0096 \\
(0.009)\end{array}$ & $\begin{array}{l}0.0042 \\
(0.009)\end{array}$ \\
\hline$P R O_{i} * \triangle L n R E E R_{i t-1}$ & & $\begin{array}{c}0.0224 * * \\
(0.011)\end{array}$ & & $\begin{array}{l}0.0094 \\
(0.008)\end{array}$ & $\begin{array}{c}0.0149 * \\
(0.009)\end{array}$ & $\begin{array}{c}0.0182 * \\
(0.010)\end{array}$ \\
\hline$S O E_{i} * \Delta \operatorname{LnREER_{it}}$ & $\begin{array}{c}-0.4431^{* *} \\
(0.220)\end{array}$ & $\begin{array}{c}-0.5789 * * \\
(0.269)\end{array}$ & & & $\begin{array}{c}-0.5521^{* *} \\
(0.261)\end{array}$ & \\
\hline$S O E_{i} * \Delta \operatorname{LnREER_{it-1}}$ & $\begin{array}{l}0.0219 \\
(0.274)\end{array}$ & $\begin{array}{c}-0.3778 \\
(0.294)\end{array}$ & & & $\begin{array}{l}-0.3146 \\
(0.314)\end{array}$ & \\
\hline$P V T_{i} * \Delta \operatorname{LnREER_{it}}$ & & & $\begin{array}{l}0.2657 \\
(0.249)\end{array}$ & $\begin{array}{l}0.1938 \\
(0.262)\end{array}$ & $\begin{array}{l}0.1499 \\
(0.246)\end{array}$ & \\
\hline$P V T_{i} * \Delta \operatorname{LnREER_{it-1}}$ & & & $\begin{array}{c}0.5696 * * * \\
(0.218)\end{array}$ & $\begin{array}{c}0.4397 * * \\
(0.209)\end{array}$ & $\begin{array}{c}0.4395^{* *} \\
(0.211)\end{array}$ & \\
\hline$F D I S_{i} * \Delta \operatorname{LnREER_{it}}$ & & & & & & $\begin{array}{c}-0.6653^{* * *} \\
(0.224)\end{array}$ \\
\hline$F D I S_{i} * \Delta L n R E E R_{i t-1}$ & & & & & & $\begin{array}{c}-0.6271^{* *} \\
(0.257)\end{array}$ \\
\hline Observations & 2,961 & 2,961 & 2,961 & 2,961 & 2,961 & 2,950 \\
\hline Number of Ind. & 456 & 456 & 456 & 456 & 456 & 453 \\
\hline Time Dummy & Yes & Yes & Yes & Yes & Yes & Yes \\
\hline $\begin{array}{l}\text { Autocorrelation Test } \\
\text { AR(2)(P_value) }\end{array}$ & 0.703 & 0.749 & 0.641 & 0.655 & 0.73 & 0.334 \\
\hline $\begin{array}{l}\text { Over Identification Test } \\
\text { Hansen } J \text { (P_value) }\end{array}$ & 0.418 & 0.477 & 0.518 & 0.546 & 0.516 & 0.379 \\
\hline \multicolumn{7}{|c|}{ Instrument Subset Exgenoeity Test } \\
\hline Hansen Test & 0.742 & 0.754 & 0.63 & 0.629 & 0.73 & 0.648 \\
\hline Difference & 0.079 & 0.128 & 0.282 & 0.341 & 0.202 & 0.106 \\
\hline
\end{tabular}

Notes: The employment equations are all identified using the two-step system Generalized Moment Method estimators. $\triangle L n L_{i t-1}, \Delta L n Y_{i t}$ and $\Delta L n W a g e_{i t}^{*}$ are set as endogenous variables based on the panel IV endogenous tests. Robust standard errors are computed below the coefficients to correct the downward bias of standard errors; ****, $(* *, *)$ indicates rejection of null hypothesis is significant at $1 \%,(5 \%, 10 \%)$. 
Table 4 Trade Openness, Profit Margins and Real Exchange Rate Movement Effects on Wage Rates (Dependent Variable: $\Delta$ LnWage $e_{i t}$ )

\begin{tabular}{|c|c|c|c|c|c|c|}
\hline \multirow{2}{*}{ Independent Variables } & \multicolumn{4}{|c|}{ FE-IV/2SLS } & \multicolumn{2}{|c|}{ FE-IV/GMM Two Step } \\
\hline & ALL Ind. & HIGH PRO. & LOW PRO. & ALL Ind. & ALL Ind. & ALL Ind. \\
\hline \multirow[t]{2}{*}{$\triangle \operatorname{Ln} Y_{i t}$} & $0.0528 *$ & $0.0869 * * *$ & 0.0347 & $0.0525 *$ & $0.0474 *$ & $0.0473 *$ \\
\hline & $(0.029)$ & $(0.032)$ & $(0.044)$ & $(0.029)$ & $(0.028)$ & $(0.029)$ \\
\hline \multirow[t]{2}{*}{$\Delta$ LnWage $_{i t}^{*}$} & $0.3542^{* * *}$ & 0.0839 & $0.5446 * * *$ & $0.3532^{* * *}$ & $0.3928 * * *$ & $0.3919 * * *$ \\
\hline & $(0.095)$ & $(0.139)$ & $(0.124)$ & $(0.094)$ & $(0.091)$ & $(0.091)$ \\
\hline \multirow[t]{2}{*}{$\Delta \operatorname{Ln} L_{i t-1}$} & $-0.0338 *$ & $-0.0402 * *$ & -0.0285 & $-0.0340 * *$ & $-0.0312 *$ & $-0.0314^{*}$ \\
\hline & $(0.017)$ & $(0.020)$ & $(0.026)$ & $(0.017)$ & $(0.017)$ & $(0.017)$ \\
\hline \multirow[t]{2}{*}{$T O_{i} * \Delta \operatorname{Ln} Y_{i t}^{*}$} & $0.9310^{* * *}$ & $1.1642^{* * *}$ & 0.6556 & $0.9062^{* * *}$ & $0.8874 * * *$ & $0.8602 * *$ \\
\hline & $(0.345)$ & $(0.412)$ & $(0.567)$ & $(0.347)$ & $(0.339)$ & $(0.341)$ \\
\hline \multirow[t]{2}{*}{$E X S_{i} * \triangle L n R E E R_{i t}$} & $-0.6618^{* * *}$ & $-1.6153 * * *$ & -0.2961 & $-0.6568 * * *$ & $-0.6365 * * *$ & $-0.6275 * * *$ \\
\hline & $(0.225)$ & $(0.363)$ & $(0.299)$ & $(0.230)$ & $(0.224)$ & $(0.228)$ \\
\hline \multirow[t]{2}{*}{$E X S_{i} * \triangle L n R E E R_{i t-1}$} & $-0.4585^{* *}$ & 0.4643 & $-0.8835 * * *$ & $-0.4730 * *$ & $-0.4404^{* *}$ & $-0.4568 * *$ \\
\hline & $(0.223)$ & $(0.382)$ & $(0.285)$ & $(0.225)$ & $(0.222)$ & $(0.225)$ \\
\hline \multirow{2}{*}{$I M S_{i} * \Delta \operatorname{LnREER_{it}}$} & -0.1492 & -0.2486 & 0.0686 & -0.1294 & -0.126 & -0.0989 \\
\hline & $(0.183)$ & $(0.230)$ & $(0.302)$ & $(0.194)$ & $(0.182)$ & $(0.193)$ \\
\hline \multirow[t]{2}{*}{$I M S_{i} * \Delta \operatorname{LnREER_{it-1}}$} & $-0.3353^{* *}$ & $-0.4243 * *$ & -0.3756 & $-0.3765^{* *}$ & $-0.3544 * * *$ & $-0.3995 * *$ \\
\hline & $(0.135)$ & $(0.171)$ & $(0.233)$ & $(0.159)$ & $(0.134)$ & $(0.158)$ \\
\hline \multirow[t]{2}{*}{$P R O_{i} * \triangle L n R E E R_{i t}$} & & & & -0.0025 & & -0.0037 \\
\hline & & & & $(0.010)$ & & $(0.010)$ \\
\hline \multirow[t]{2}{*}{$P R O_{i} * \Delta \operatorname{LnREER_{it-1}}$} & & & & 0.0074 & & 0.0083 \\
\hline & & & & $(0.010)$ & & $(0.010)$ \\
\hline $\begin{array}{l}\text { Net } \triangle \operatorname{LnREER} \\
\text { Effects }\end{array}$ & -0.381 & -0.455 & -0.237 & -0.400 & -0.379 & -0.400 \\
\hline Observations & 2,956 & 1,471 & 1,485 & 2,956 & 2,956 & 2,956 \\
\hline Number of Ind. & 452 & 226 & 226 & 452 & 452 & 452 \\
\hline R-squared & 0.859 & 0.859 & 0.861 & 0.859 & 0.859 & 0.859 \\
\hline Time Dummy & Yes & Yes & Yes & Yes & Yes & Yes \\
\hline \multicolumn{7}{|c|}{ Under Identification Klei.-paap.rk Test } \\
\hline LM Statistics(P-Value) & 0.000 & 0.000 & 0.000 & 0.000 & 0.000 & 0.000 \\
\hline \multicolumn{7}{|l|}{ Over Identification Test: } \\
\hline Hansen J( P-Value) & 0.298 & 0.558 & 0.526 & 0.292 & 0.298 & 0.292 \\
\hline \multicolumn{7}{|c|}{ Endogenous Variables Test $\left(\Delta Y_{i t} ; \Delta \operatorname{LnWage_{it}^{*})}\right.$} \\
\hline (P-Value) & 0.012 & 0.008 & 0.046 & 0.010 & 0.012 & 0.010 \\
\hline
\end{tabular}

Notes: The wage equations are identified using fixed effect-Instrument/2SLS and fixed effect-Instrument/GMM estimators respectively. $\Delta \operatorname{LnY} Y_{i t}$ and $\Delta L n W a g e_{i t}^{*}$ are set as endogenous variables based on the panel IV endogenous tests. The one and two term lagged endogenous level variables are set as instrument variables for the differenced endogenous variables. Robust standard errors are computed below the coefficients to correct the, heteroskedasticity and autocorrelation of error terms; ****, $(* *, *)$ indicates rejection of null hypothesis is significant at $1 \%$, (5\%, 10\%). 
Table 5 Ownership Characteristics and Real Exchange Rate Movement Effects on Wage Rates (Dependent Variable: $\triangle$ LnWage $_{i t}$ )

\begin{tabular}{|c|c|c|c|c|c|c|}
\hline Independent Variables & (1) & (2) & (3) & (4) & (5) & (6) \\
\hline$\Delta \operatorname{Ln} Y_{i t}$ & $\begin{array}{c}0.0477^{*} \\
(0.029)\end{array}$ & $\begin{array}{l}0.0441 \\
(0.029)\end{array}$ & $\begin{array}{l}0.0408 \\
(0.029)\end{array}$ & $\begin{array}{l}0.0386 \\
(0.029)\end{array}$ & $\begin{array}{l}0.0442 \\
(0.029)\end{array}$ & $\begin{array}{l}0.0382 \\
(0.029)\end{array}$ \\
\hline$\Delta$ LnWage $e_{i t}^{*}$ & $\begin{array}{c}0.3893 * * * \\
(0.090)\end{array}$ & $\begin{array}{c}0.3724 * * * \\
(0.092)\end{array}$ & $\begin{array}{c}0.4162 * * * \\
(0.090)\end{array}$ & $\begin{array}{c}0.4156^{* * *} \\
(0.089)\end{array}$ & $\begin{array}{c}0.3867^{* * *} \\
(0.089)\end{array}$ & $\begin{array}{c}0.4057^{* * *} \\
(0.089)\end{array}$ \\
\hline$\Delta L n L_{i t-1}$ & $\begin{array}{c}-0.0308^{*} \\
(0.017)\end{array}$ & $\begin{array}{c}-0.0295 * \\
(0.017)\end{array}$ & $\begin{array}{r}-0.0282 \\
(0.018)\end{array}$ & $\begin{array}{c}-0.0306 * \\
(0.017)\end{array}$ & $\begin{array}{c}-0.0309 * \\
(0.017)\end{array}$ & $\begin{array}{r}-0.0261 \\
(0.018)\end{array}$ \\
\hline$T O_{i} * \Delta L n Y_{i t}^{*}$ & $\begin{array}{c}0.8568 * * \\
(0.342)\end{array}$ & $\begin{array}{c}0.8655^{* *} \\
(0.341)\end{array}$ & $\begin{array}{c}0.8808 * * \\
(0.360)\end{array}$ & $\begin{array}{c}0.4370 * \\
(0.240)\end{array}$ & $\begin{array}{c}0.5052 * * \\
(0.234)\end{array}$ & $\begin{array}{c}0.7652 * * \\
(0.337)\end{array}$ \\
\hline$E X S_{i} * \Delta \operatorname{LnREER_{it}}$ & $\begin{array}{c}-0.6302 * * * \\
(0.232)\end{array}$ & $\begin{array}{c}-0.9257 * * * \\
(0.245)\end{array}$ & $\begin{array}{l}-0.1979 \\
(0.338)\end{array}$ & & & \\
\hline$E X S_{i} * \triangle L n R E E R_{i t-1}$ & $\begin{array}{c}-0.4312^{*} \\
(0.227)\end{array}$ & $\begin{array}{c}-0.6868 * * * \\
(0.237)\end{array}$ & $\begin{array}{l}0.1598 \\
(0.358)\end{array}$ & $\begin{array}{c}-0.3764 \\
(0.361)\end{array}$ & $\begin{array}{c}-1.0374 * * * \\
(0.217)\end{array}$ & \\
\hline$I M S_{i} * \Delta \operatorname{LnREER_{it}}$ & $\begin{array}{r}-0.0951 \\
(0.191)\end{array}$ & $\begin{array}{r}-0.1712 \\
(0.194)\end{array}$ & $\begin{array}{r}-0.2044 \\
(0.195)\end{array}$ & & & $\begin{array}{l}-0.208 \\
(0.183)\end{array}$ \\
\hline$I M S_{i} * \triangle L n R E E R_{i t-1}$ & $\begin{array}{c}-0.4132 * * * \\
(0.157)\end{array}$ & $\begin{array}{c}-0.4798 * * * \\
(0.157)\end{array}$ & $\begin{array}{c}-0.3217 * * \\
(0.159)\end{array}$ & $\begin{array}{c}-0.4970 * * * \\
(0.147)\end{array}$ & $\begin{array}{c}-0.5639 * * * \\
(0.144)\end{array}$ & $\begin{array}{c}-0.4198 * * * \\
(0.155)\end{array}$ \\
\hline$P R O_{i} * \triangle \operatorname{LnREER_{it}}$ & $\begin{array}{r}-0.0033 \\
(0.012)\end{array}$ & $\begin{array}{c}-0.0199 * \\
(0.011)\end{array}$ & $\begin{array}{l}0.0002 \\
(0.010)\end{array}$ & & & $\begin{array}{l}-0.0104 \\
(0.013)\end{array}$ \\
\hline$P R O_{i} * \triangle L n R E E R_{i t-1}$ & $\begin{array}{l}0.0054 \\
(0.012)\end{array}$ & $\begin{array}{r}-0.0042 \\
(0.011)\end{array}$ & $\begin{array}{l}0.0134 \\
(0.010)\end{array}$ & $\begin{array}{r}-0.0075 \\
(0.012)\end{array}$ & $\begin{array}{r}-0.0181 \\
(0.013)\end{array}$ & $\begin{array}{r}-0.0011 \\
(0.013)\end{array}$ \\
\hline$S O E_{i} * \triangle \operatorname{LnREER} R_{i t}$ & $\begin{array}{r}-0.0423 \\
(0.271)\end{array}$ & & & & & $\begin{array}{r}-0.0628 \\
(0.279)\end{array}$ \\
\hline$S O E_{i} * \Delta L n R E E R_{i t-1}$ & $\begin{array}{l}0.1782 \\
(0.320)\end{array}$ & & & $\begin{array}{l}0.2157 \\
(0.257)\end{array}$ & $\begin{array}{l}0.3574 \\
(0.262)\end{array}$ & $\begin{array}{l}0.2379 \\
(0.316)\end{array}$ \\
\hline$P V T_{i} * \triangle \operatorname{LnREER_{it}}$ & & $\begin{array}{c}0.7880^{* * *} \\
(0.229)\end{array}$ & & & & $\begin{array}{c}0.4867 * * \\
(0.233)\end{array}$ \\
\hline$P V T_{i} * \triangle L n R E E R_{i t-1}$ & & $\begin{array}{c}0.6651^{* *} \\
(0.259)\end{array}$ & & $\begin{array}{c}0.8810^{* * *} \\
(0.253)\end{array}$ & $\begin{array}{c}1.0606 * * * \\
(0.251)\end{array}$ & $\begin{array}{c}0.5687 * * \\
(0.249)\end{array}$ \\
\hline$F D I S_{i} * \Delta \operatorname{LnREER_{it}}$ & & & $\begin{array}{c}-0.5752 * \\
(0.341)\end{array}$ & & & $\begin{array}{c}-0.7597 * * * \\
(0.235)\end{array}$ \\
\hline$F D I S_{i} * \Delta \operatorname{LnREER_{it-1}}$ & & & $\begin{array}{c}-0.7267 * \\
(0.376) \\
\end{array}$ & $\begin{array}{c}-0.7785 * * \\
(0.336) \\
\end{array}$ & & $\begin{array}{c}-0.6226 * * * \\
(0.235) \\
\end{array}$ \\
\hline Observations & 2,956 & 2,956 & 2,946 & 2,946 & 2946 & 2,946 \\
\hline Number of id & 452 & 452 & 450 & 450 & 450 & 450 \\
\hline R-squared & 0.859 & 0.861 & 0.861 & 0.861 & 0.860 & 0.862 \\
\hline Time Dummy & Yes & Yes & Yes & Yes & Yes & Yes \\
\hline \multicolumn{7}{|c|}{ Under Identification Test(P-Value) } \\
\hline Kleibergen-paap rk LM & 0.000 & 0.000 & 0.000 & 0.000 & 0.000 & 0.000 \\
\hline \multicolumn{7}{|c|}{ Over Identification Test(P-Value) } \\
\hline Hansen $\mathrm{J}$ & 0.288 & 0.233 & 0.352 & 0.211 & 0.162 & 0.297 \\
\hline \multicolumn{7}{|c|}{ Endogenous Variables Test $\left(\Delta Y_{i t} ; \Delta \operatorname{LnWage_{it}^{*}}\right)$} \\
\hline (P-Value) & 0.010 & 0.020 & 0.016 & 0.015 & 0.013 & 0.024 \\
\hline
\end{tabular}

Notes: The wage equations are identified using fixed effect-Instrument/GMM estimators. $\triangle \operatorname{LnY} Y_{i t} ; \Delta \operatorname{LnWage} e_{i t}^{*}$ are set as endogenous variables based on the panel IV endogenous tests. The one and two term lagged endogenous level variables are set as instrument variables for the differenced endogenous variables. Robust standard errors are computed below the coefficients to correct the heteroskedasticity and autocorrelation of error terms; ****, $\left({ }^{* *}, *\right)$ indicates rejection of null hypothesis is significant at $1 \%$, (5\%, 10\%). 


\section{Reference}

Alexandre,F., Bacao, P., Cerejeira, J. and Portela,M., 2010, Employment ,Exchange rate and Labor Market Rigidity, IZA Discussion Paper No. 4891.

Arellano, M. and Bover,O., 1995, Another Look at the Instrumental Variable Estimation of Error-Components Models. Journal of Econometrics, 68, 29-51.

Blundell,R. and Bond, S., 1998, Initial Conditions and Moment Restrictions in Dynamic Panel Data Models. Journal of Econometrics, 87, 115-143.

Branson, W. and Love, J., 1988, United States Manufacturing and the Real Exchange Rate. In: Marston, R.(Ed.), Misalignment of Exchange Rates: Effects on Trade and Industry. University of Chicago Press,Chicago, Illinois.

Buckley, P., Wang C. and Jeremy, C., 2007, The Impact of Foreign Ownership, Local Ownership and Industry Characteristics on Spillover Benefits from Foreign Direct Investment in China” International Business Review, 16(2), 142-158

Burgess,S.M. and Knetter, M.M.,1998, An International Comparison of Employment Adjustment to Exchange Rate Fluctuations, Review of International Economics, 6(1), 151-163.

Campa, J. and Goldberg, L., 2001, Employment Versus Wage Adjustment and the U.S. Dollar. Review of Economics and Statistics, 83 (3), 477-489.

Dekle,R.,1998, The Yen and Japanese Manufacturing Employment, Journal of International Money and Finance,17,785-801.

Goldberg, L., 2004, Industry Specific Real Exchange Rate for the United States, Economic Policy Review,10(1), 1-16.

Goldberg, L . and Tracy, j., 2001, Exchange Rates and Wages, NBER working paper w8137.

Hale, G. and Long, C., 2008, Did Foreign Direct Investment Put an Upward Pressure on Wages in China, Federal Reserve Bank of San Francisco Working Paper Series 2006-25

Klein, M.W., Schuh,S. and Triest, R.K., 2003, Job creation, Job destruction and the Real Exchange Rate, Journal of International Economics, 59, 239-265.

McKinnon, R., 2005, Exchange Rate or Wage Changes in International Adjustment? Japan and China versus United States. ZEW-Centre for European Economic Research Discussion Paper No.05-064.

McKinnon,R. and Schnabl, G., 2006, China's Exchange Rate and International Adjustment in Wages, Prices and Interest Rates: Japan De’ja` $V u$ ? CESifo Economic Studies, Vol.52,2/2006,267-303.

Nucci, F. and Pozzolo, Alberto F., 2010, The Exchange Rate, Employment and Hours: What Firm Level Data Say? Journal of International Economics, 82, 112-123

Ping, Hua, 2007, Real Exchange Rate and Manufacturing Employment in China, China Economic Review,18, 335-353.

Revenga, A., 1992, Exporting jobs? The Impact of Import Competition on Employment and Wages in U.S. Manufacturing, Quarterly Journal of Economics 107 (1), 255-284. 
Appendix Trade openness, Ownership characteristics, Industry Specific Real Exchange Rates and Foreign income

The overall average trade openness variable for 2001-2009 for industry $i\left(\mathrm{TO}_{i}\right)$ is defined as

$$
\mathrm{TO}_{i}=0.54 \frac{\sum_{t=2001}^{t=2009} E X_{i t}}{\sum_{t=2001}^{t=2009} P_{i t}}+0.46 \frac{\sum_{t=2001}^{t=2009} I M_{i t}}{\sum_{t=2001}^{t=2009}\left(P_{i t}+I M_{i t}\right)}
$$

where 0.54 is the average ratio of total export goods to total trade goods and 0.46 is the average ratio of total import goods to total trade goods for China over the period of 2001 to 2009.

Average 2001 to 2009 export openness by industry is defined as

$$
E X S_{i}=\frac{\sum_{t=2001}^{t=2009} E X_{i t}}{\sum_{t=2001}^{t=2009} P_{i t}}
$$

Overall average 2001 to 2009 import penetration rate by industry is defined as

$$
I M S_{i}=\frac{\sum_{t=2001}^{t=2009} I M_{i t}}{\sum_{t=2001}^{t=2009}\left(P_{i t}+I M_{i t}\right)}
$$

Average shares of different ownership enterprises by industry over the period of 2001 to 2009 are defines as

$$
S O E_{i}=\frac{\sum_{t=2001}^{t=2009} S P_{i t}}{\sum_{t=2001}^{t=209} P_{i t}} \quad P^{t} T_{i}=\frac{\sum_{t=2001}^{t=2009} P P_{i t}}{\sum_{t=2001}^{t=2009} P_{i t}} \quad F D I S_{i}=\frac{\sum_{t=2001}^{t=2009} F P_{i t}}{\sum_{t=2001}^{t=2009} P_{i t}}
$$

where $\mathrm{SP}_{i t}, P P_{i t}$ and $F P_{i t}$ represent the total production of SOEs, private enterprises and FIEs respectively.

Following Goldberg (2004), industry specific real exchange rates and foreign income by industry are defined as

$$
\begin{gathered}
R E E R_{i t}=\sum_{j=1}^{k} \omega_{j t}^{i} R E R_{j t} \quad Y_{i t}^{*}=\sum_{j=1}^{k} \omega_{j t}^{i} Y_{j t} \\
\omega_{j t}^{i}=0.54 * \frac{\sum_{c=t-2}^{t-1} e x_{j c}^{i}}{\sum_{j=1}^{k} \sum_{c=t-2}^{t-1} e x_{j c}^{i}}+0.46 * \frac{\sum_{c=t-2}^{t-1} i m_{j c}^{i}}{\sum_{j=1}^{k} \sum_{c=t-2}^{t-1} i m_{j c}^{i}}
\end{gathered}
$$

where $e x_{j c}^{i}$ represent the value exported by China to its trade partner $j$ in the specific sector $i$ at the period of $c$; and $i m_{j c}^{i}$ represent the value imported by China from its trade partner $j$ in the specific sector $i$ at the period of $c$. 